\title{
Clotting Time of Common Carp Blood
}

\author{
Hiroshi Kawatsu* \\ (Accepted August 20, 1985)
}

\begin{abstract}
Recalcification time, prothrombin time (PT), partial thromboplastin time (PTT) and activated partial thromboplastin time (APTT) were determined for common carp plasma. Clotting times were $37.6 \pm 8.7 \mathrm{~s}($ mean $\pm \mathrm{SD})$ recalcification time, $23.5 \pm 3.4 \mathrm{~s}$ PT, $17.9 \pm 3.2 \mathrm{~s}$ PTT, and $5.1 \pm 0.7 \mathrm{~s}$ APTT, respectively. The difference between APTT and PTT suggests that the intrinsic hemostatic system is developed in carp blood. Citrated plasma lost its clotting activity within $12 \mathrm{~h}$ during incubation at $37^{\circ} \mathrm{C}$, whereas clotting activity was maintained for long hours at $25^{\circ} \mathrm{C}$. The shortest clotting time was obtained for the mixture of $\mathrm{BaSO}_{4}$ adsorbed plasma and serum. This indicates that coagulation factors of carp blood can be classified into the serum factors and barium sulphate adsorbed factors.
\end{abstract}

The blood coagulation mechanism in fishes has been investigated from two standpoints: comparative physiology and fish pathology. Teleost fish blood clots very rapidly, while elasmobranch blood clots very slowly.:-3) The blood of cyclostome lacks intrinsic clotting activity. ${ }^{1)}$ Clotting time is dependent on the concentration of sodium chloride, of which the optimum concentration is different between marine and freshwater fish. ${ }^{4)}$ The effect of temperature on the clotting time is different between warm and cold-water fish. The latter blood clots rapidly at low temperature. ${ }^{3)}$

Retardation of the clotting time has been observed in sick fish, ${ }^{8)}$ spent fish, ${ }^{7>}$ and in fish being exposed to chromium, ${ }^{2}$ dehydroabietic acid, ${ }^{8)}$ and molinate. ${ }^{10)}$ On the other hand, shortening of the clotting time has been reported in fishes exposed to cobalt, ${ }^{11)}$ malathion, ${ }^{12)}$ and chlordane. ${ }^{13)}$ It has been demonstrated that the clotting time declines and thrombocyte count increases after stress. ${ }^{14,15)}$ It seems that many factors may be involved in these alterations of the clotting time. The present paper aims to establish a standard procedure for the determination of clotting time in order to detect the factors associated with disorders in the hemostatic system in common carp blood.

\section{Materials and Methods}

Test Animal

Common carp Cyprinus carpio was used for the experiments. Fish were obtained from a private fish farm and kept in the ponds until used.

\section{Preparation of Citrated Plasma, Serum and Adsorbed Plasma}

Citrated plasma: Blood was taken from the caudal vessel using plastic syringes. Nine volumes of the blood were withdrawn into a syringe already containing 1 volume of $3.13 \%$ trisodium citrate solution. Plasma was obtained by centrifugation at 3,000 rpm for $5 \mathrm{~min}$. Equal volumes of the plasma samples collected from three or four individuals were pooled except that the clotting time was determined individually.

Serum: Clotted blood was left at room temperature for $1 \mathrm{~h}$ and was centrifuged at 3,000 rpm for $5 \mathrm{~min}$. Three or four serum samples were pooled and stored at $4^{\circ} \mathrm{C}$ for 2 or 3 days until used.

Adsorbed plasma with $\mathrm{BaSO}_{4}$ : Barium sulphate was added to the pooled citrated plasma (200 $\mathrm{mg} / \mathrm{m} /$ plasma) and stirred with a glass rod for $15 \mathrm{~min}$ at $25^{\circ} \mathrm{C}$. After centrifugation at 3,000 rpm for $5 \mathrm{~min}$, the supernatant was stored at $4^{\circ} \mathrm{C}$.

Adsorbed plasma with bentonite: Bentonite (Kanto Kagaku Co. Ltd., Tokyo) was added to the citrated plasma $(50 \mathrm{mg} / \mathrm{ml}$ plasma) and stirred with a glass rod for $10 \mathrm{~min}$ at $25^{\circ} \mathrm{C}$. After centrifugation at $3,000 \mathrm{rpm}$ for $15 \mathrm{~min}$, the supernatant was stored at $4^{\circ} \mathrm{C}$.

Stored citrated plasma: Citrated plasma was incubated at $25^{\circ} \mathrm{C}$ and $37^{\circ} \mathrm{C}$ for $24 \mathrm{~h}$ according to the purpose of the experiment.

* Department of Fisheries, Faculty of Agriculture, Miyazaki University, Kumano, Miyazaki 889-21, Japan (川津浩品: 宮崎大学農学部水産增殖学科). 
Procedures for Determination of the Clotting Time

Recalcification time: One-tenth $\mathrm{m} l$ of citrated plasma was pipetted into a $10 \times 90 \mathrm{~mm}$ test tube and placed in a $25^{\circ} \mathrm{C}$ or $37^{\circ} \mathrm{C}$ water bath for $3 \mathrm{~min}$. Then, $0.1 \mathrm{~m} l$ of $\mathrm{m} / 40$ calcium chloride solution being kept at the test temperature was added and a stop-watch was started. After adding calcium chloride solution, the lower end of the test tube was moved every second so that the liquid content of the tube flowed up and down the length of the tube for a distance of 1-2 cm. When the tube could be tilted to a horizontal position without the gel moving, the watch was stopped and the time was noted. Duplicate readings were obtained from each sample and their mean clotting time was recorded.

Prothrombin time (PT): A commercially avialable complete thromboplastin, "Activated thromboplastin" (International Reagent Corp., Tokyo) was used. A complete thromboplastin-calcium chloride mixture was prepared by mixing equal volumes of "Activated thromboplastin" and $\mathrm{m} / 40$ calcium chloride solution. This mixture was kept in a water bath at $37^{\circ} \mathrm{C}$ prior to use. In this study PT was determined using 4-fold diluted plasma (one part of the citrated plasma was diluted with 3 parts of saline). One-tenth $\mathrm{ml}$ of the diluted plasma was pipetted into a $10 \times 90 \mathrm{~mm}$ test tube and placed in a $37^{\circ} \mathrm{C}$ water bath for $3 \mathrm{~min}$. Then, $0.2 \mathrm{ml}$ of complete thromboplastin-calcium chloride mixture was added and a stop-watch was started. The test tube was moved in the same manner as described in the determination of the recalcification time. The first appearance of a fibrin web was taken as the clotting time. Duplicate readings were obtained from each plasma sample and their mean clotting time was recorded.

Partial thromboplastin time (PTT): A commercially available partial thromboplastin reagent, "Platelin" (Warner-Lambert Co., New Jersey, USA) was used. Reconstituted "Platein" solution was kept at $37^{\circ} \mathrm{C}$ prior to use. One-tenth $\mathrm{m} l$ of the citrated plasma was pipetted into a $10 \times 90$ $\mathrm{mm}$ test tube and placed in a $37^{\circ} \mathrm{C}$ water bath for $1 \mathrm{~min}$. Then, $0.1 \mathrm{ml}$ of "Platelin" solution was added and the mixture allowed to stand for $2 \mathrm{~min}$. Finally, $0.1 \mathrm{~m} l$ of $\mathrm{m} / 40$ calcium chloride solution was added and a stop-watch was started. The test tube was moved in the same manner as described in the determination of the recalcification time. The clotting time was taken as the time when the fibrin clot formed. Duplicate readings were obtained from each plasma sample and their mean clotting time was recorded.

Activated partial thromboplastin time (APTT): A commercially available activated partial thromboplastin reagent, "Actin" (Dade diagnostic, Inc., Aguada, Puerto Rico) was used. This reagent is cephalin extracted from dehydrated rabbit brain in $1.0 \times 10^{-4} \mathrm{M}$ ellagic acid with added buffer, stabilizers and preservative. One-tenth $\mathrm{ml}$ of "Actin" solution was pipetted into a $10 \times 90 \mathrm{~mm}$ test tube and kept in a $37^{\circ} \mathrm{C}$ water bath for $1 \mathrm{~min}$. Then, $0.1 \mathrm{~m} l$ of the citrated plasma was added and kept for $2 \mathrm{~min}$. Finally, $0.1 \mathrm{ml}$ of $\mathrm{M} / 40$ calcium chloride solution was added and a stopwatch was started. The test tube was moved in the same manner as described in the determination of the recalcification time. The clotting time was taken as the time when a fibrin clot formed. Duplicate readings were obtained from each sample and their mean clotting time was recorded.

\section{Results}

\section{Recalcification Time}

The recalcification times were determined at $25^{\circ} \mathrm{C}$ and $37^{\circ} \mathrm{C}$ for each of 10 plasma samples. The mean value was $52.7 \mathrm{~s}$ at $25^{\circ} \mathrm{C}$ and $37.6 \mathrm{~s}$ at $37^{\circ} \mathrm{C}$, respectively (Table 1 ). The clotting time obtained at $25^{\circ} \mathrm{C}$ was prolonged about $15 \mathrm{~s}$ longer than that at $37^{\circ} \mathrm{C}$.

\section{Changes of Recalcification Time during Incubation at $4^{\circ} \mathrm{C}, 25^{\circ} \mathrm{C}$ and $37^{\circ} \mathrm{C}$}

Pooled citrated plasma samples sub-divided into 3 tubes were incubated at $4^{\circ} \mathrm{C}, 25^{\circ} \mathrm{C}$ and $37^{\circ} \mathrm{C}$, and recalcification time was determined for each sample at intervals of $1-12 \mathrm{~h}$ (Table 2). The

Table 1. Recalcification time determined at $25^{\circ} \mathrm{C}$ and $37^{\circ} \mathrm{C}$

\begin{tabular}{|c|c|c|c|c|}
\hline \multirow{2}{*}{$\begin{array}{l}\text { Sample } \\
\text { No. }\end{array}$} & \multirow{2}{*}{$\begin{array}{l}\text { Body } \\
\text { weight } \\
\text { (g) }\end{array}$} & \multicolumn{2}{|c|}{$\begin{array}{l}\text { Recalcification time } \\
(\mathrm{s})\end{array}$} & \multirow{2}{*}{$\begin{array}{c}\mathrm{A}-\mathrm{B} \\
(\mathrm{s})\end{array}$} \\
\hline & & $\begin{array}{l}25^{\circ} \mathrm{C} \\
\text { (A) }\end{array}$ & $\begin{array}{l}37^{\circ} \mathrm{C} \\
\text { (B) }\end{array}$ & \\
\hline 1 & 210 & 37.9 & 27.1 & 10.8 \\
\hline 2 & 220 & 43.1 & 32.8 & 10.3 \\
\hline 3 & 235 & 47.1 & 37.9 & 9.2 \\
\hline 4 & 195 & 47.5 & 28.5 & 19.0 \\
\hline 5 & 200 & 48.9 & 32.8 & 16.1 \\
\hline 6 & 225 & 52.3 & 32.8 & 19.5 \\
\hline 7 & 210 & 53.8 & 38.6 & 15.2 \\
\hline 8 & 295 & 57.4 & 42.7 & 14.7 \\
\hline 9 & 390 & 69.0 & 44.8 & 24.2 \\
\hline 10 & 265 & 69.7 & 58.1 & 11.6 \\
\hline mean $\pm \mathrm{SD}$ & & \multicolumn{3}{|c|}{$52.7 \pm 9.8 \quad 37.6 \pm 8.7 \quad 15.1 \pm 4.6$} \\
\hline
\end{tabular}


Table 2. Changes of recalcification time during incubations at $4^{\circ} \mathrm{C}, 25^{\circ} \mathrm{C}$ and $37^{\circ} \mathrm{C}$

\begin{tabular}{cccc}
\hline $\begin{array}{c}\text { Incubation } \\
\text { time (h) }\end{array}$ & $37^{\circ} \mathrm{C}$ & $25^{\circ} \mathrm{C}$ & $4^{\circ} \mathrm{C}$ \\
\hline 0 & $45.4 \mathrm{~s}$ & 45.4 & 45.4 \\
1 & 57.2 & 44.4 & - \\
3 & 86.4 & 48.0 & - \\
5 & 144.9 & - & - \\
6 & - & 50.3 & 50.9 \\
7 & incomplete & - & - \\
12 & & 58.8 & 62.7 \\
24 & & 67.8 & 63.7 \\
\hline
\end{tabular}

Table 3. Prothrombin time (PT), partial thromboplastin time (PTT) and activated partial thromboplastin time (APTT) of carp plasma

\begin{tabular}{ccccc}
\hline Sample No. & $\begin{array}{c}\text { Body } \\
\text { weight } \\
(\mathrm{g})\end{array}$ & $\begin{array}{c}\text { PT } \\
(\mathrm{s})\end{array}$ & $\begin{array}{c}\text { PTT } \\
(\mathrm{s})\end{array}$ & $\begin{array}{c}\text { APTT } \\
(\mathrm{s})\end{array}$ \\
\hline 1 & 256 & 17.3 & 13.4 & 4.2 \\
2 & 255 & 20.7 & 15.8 & 4.7 \\
3 & 263 & 21.3 & 16.7 & 4.7 \\
4 & 228 & 21.7 & 15.6 & 5.3 \\
5 & 262 & 22.7 & 19.2 & 4.8 \\
6 & 272 & 23.0 & 16.7 & 5.4 \\
7 & 259 & 25.0 & 17.9 & 4.7 \\
8 & 245 & 25.7 & 17.6 & 5.3 \\
9 & 304 & 27.7 & 21.6 & 5.3 \\
10 & 257 & 29.7 & 25.3 & 6.9 \\
\hline mean & & 23.5 & 17.9 & 5.1 \\
\pm SD & & \pm 3.4 & \pm 3.2 & \pm 0.7 \\
\hline
\end{tabular}

clotting time of the original pooled plasma was $45.4 \mathrm{~s}$. Under incubation at $37^{\circ} \mathrm{C}$, the clotting time rapidly increased and exceeded 2 min after $5 \mathrm{~h}$. Fibrin clot formation was incomplete after $7 \mathrm{~h}$ and consequently the end point was indistinct. Under incubation at $25^{\circ} \mathrm{C}$ and $4^{\circ} \mathrm{C}$, the clotting time gradually increased and reached $67.8 \mathrm{~s}$ and $63.7 \mathrm{~s}$ after $24 \mathrm{~h}$, respectively. No significant difference was observed between the clotting times of the plasma incubated at $25^{\circ} \mathrm{C}$ and $4^{\circ} \mathrm{C}$.

\section{Prothrombin Time $(P T)$}

The PT, PTT and APTT were determined for 10 plasma samples (Table 3). Mean, standard deviation, and range of the PT were $23.5 \mathrm{~s}, 3.4 \mathrm{~s}$ and $17.3-29.7 \mathrm{~s}$, respectively.

\section{PT of Graded Dilutions of the Plasma in Saline}

A serially diluted plasma was prepared by diluting $1: 2,1: 4,1: 8,1: 16$, and $1: 32$, in saline. Each dilution should have 50,25, 12.5, 6.25 and

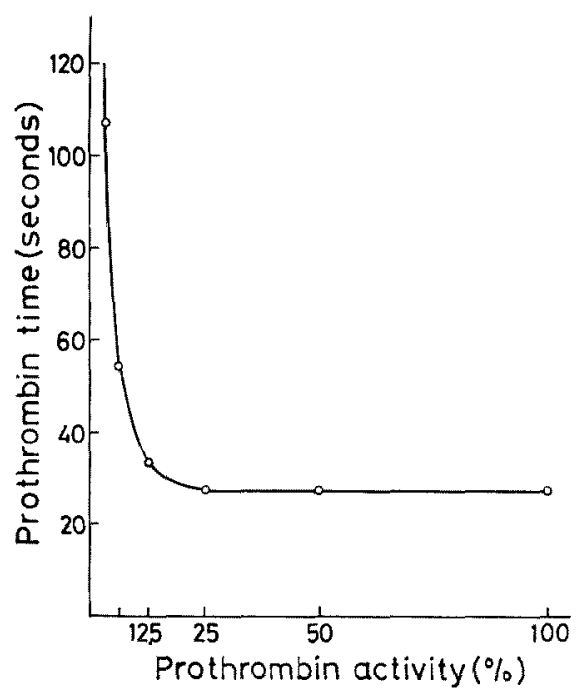

Fig. 1. Prothrombin time (PT) of graded dilutions of plasma in saline.

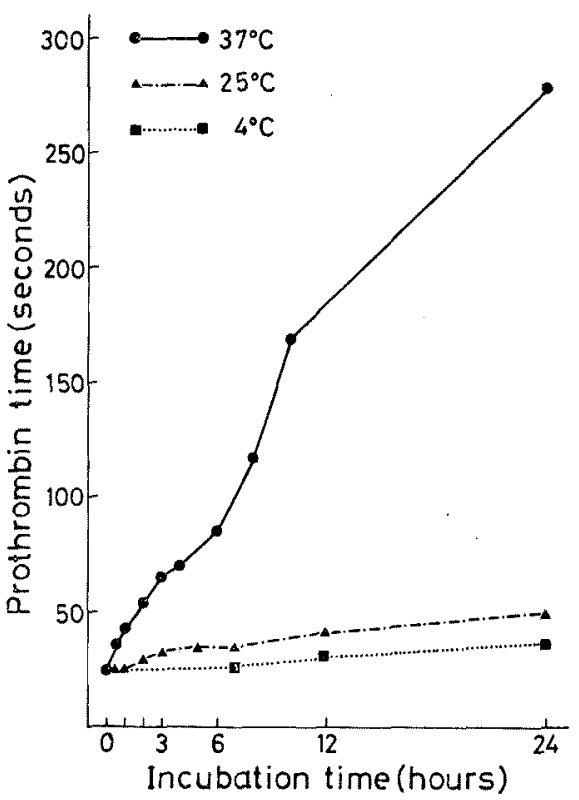

Fig. 2. Changes of prothrombin time (PT) during incubations at $4^{\circ} \mathrm{C}, 25^{\circ} \mathrm{C}$ and $37^{\circ} \mathrm{C}$.

$3.13 \%$ activities, respectively. For each dilution, PT was determined. The PT of graded dilutions of the plasma in saline were plotted against the plasma concentration (Fig. 1). No difference was found in PT between the original plasma and 4-fold dilution ( $25 \%$ concentration), but remarkable increase was recorded at more than 8-fold 
Table 4. Prothrombin time (PT) of plasma mixtures

\begin{tabular}{lcccc}
\hline & & \multicolumn{2}{c}{ PT (seconds) after mixing with } \\
\cline { 4 - 5 } & $\begin{array}{c}\text { PT (seconds) } \\
\text { before mixing }\end{array}$ & $\begin{array}{c}\text { BaSO } \\
\text { plasma }\end{array}$ & $\begin{array}{c}\text { Stored } \\
\text { serum }\end{array}$ & $\begin{array}{c}\text { Bentonite } \\
\text { adsorbed } \\
\text { plasma }\end{array}$ \\
\hline $\begin{array}{l}\text { Citrated plasma incubated at } 37^{\circ} \mathrm{C} \\
\text { for } 24 \mathrm{~h}\end{array}$ & $63^{*}$ & 70 & 37 & 63 \\
$\begin{array}{l}\text { BaSO } \mathrm{O}_{4} \text { adsorbed plasma } \\
\text { Stored serum }\end{array}$ & $>360$ & - & 37 & 143 \\
Bentonite adsorbed plasma & $>360$ & 37 & - & $>360$ \\
\hline
\end{tabular}

* Prothrombin time of eitrated plasma was $28 \mathrm{~s}$ before incubation.

dilutions. This fact indicates that decrease of coagulation factor to $25 \%$ has no effect on PT prolongation. Although fibrin web diminished in quantity in high dilutions, it was clearly distinguishable up to 32 -fold dilution.

Changes of PT During Incubations at $4^{\circ} \mathrm{C}, 25^{\circ} \mathrm{C}$ and $37^{\circ} \mathrm{C}$

Pooled citrated plasma samples sub-divided into 3 tubes were incubated at $4^{\circ} \mathrm{C}, 25^{\circ} \mathrm{C}$ and $37^{\circ} \mathrm{C}$, and $\mathrm{PT}$ was determined for each sample at intervals of 1-12 h (Fig. 2). The PT of the original pooled plasma was $24.3 \mathrm{~s}$. Prolongations of PT during $24 \mathrm{~h}$ incubation were $12 \mathrm{~s}$ at $4^{\circ} \mathrm{C}, 25 \mathrm{~s}$ at $25^{\circ} \mathrm{C}$, and $253 \mathrm{~s}$ at $37^{\circ} \mathrm{C}$, respectively. Two phases were distinguished in the prolongations of PT. Under incubation at $37^{\circ} \mathrm{C}$, the first rapid increase was observed during the first 3 hours, and the second after $6 \mathrm{~h}$. A similar trend was found in the prolongation of PT during incubation at $25^{\circ} \mathrm{C}$. Under incubation at $4^{\circ} \mathrm{C}$, only a slow increase was observed. These trends suggest the existence of two or more heat labile coagulation factors in carp plasma.

\section{PT of the Plasma Mixtures}

In order to differentiate the coagulation factors, measurements of PT were performed on the mixtures of the following plasma and serum samples: citrated plasma incubated at $37^{\circ} \mathrm{C}$ for $24 \mathrm{~h}$, adsorbed plasma with $\mathrm{BaSO}_{4}$, adsorbed plasma with bentonite, and stored serum. To prepare the plasma mixtures, equal volumes of each plasma or serum sample were mixed.

Measurements of PT for the original plasma and serum samples were performed using 4-fold dilution with saline. To avoid the effects of dilution of the coagulation factors, 2-fold dilution with saline was used for the determination of PT of the plasma mixtures.

As shown in Table 4, PT of the citrated plasma incubated at $37^{\circ} \mathrm{C}$ was shortened by mixing with stored serum, whereas no noticeable change was observed after mixing with each of two adsorbed plasmas. This fact suggests that the heat labile coagulation factors were supplemented only from stored serum. The PT of the adsorbed plasma with $\mathrm{BaSO}_{4}$ was remarkably shortened by mixing with stored serum. On the other hand, PT of adsorbed plasma with bentonite was not shortened by mixing with serum. From these results it may be considered that the deficient coagulation factors in the adsorbed plasma with $\mathrm{BaSO}_{4}$ and the stored serum completely supplement each other by mixing. The PT of the adsorbed plasma with $\mathrm{BaSO}_{4}$ was shortened to a certain extent by mixing with the adsorbed plasma with bentonite.

\section{Partial Thromboplastin Time (PTT)}

As shown in Table 3, mean, standard deviation and range of PTT were $17.9 \mathrm{~s}, 3.2 \mathrm{~s}$ and 13.4 $25.3 \mathrm{~s}$, respectively. The correlation coefficient between PT and PTT was 0.90 .

\section{Changes of PTT during Incubation at $4^{\circ} \mathrm{C}, 25^{\circ} \mathrm{C}$ and $37^{\circ} \mathrm{C}$}

Pooled citrated plasma samples sub-divided into 3 tubes were incubated at $4^{\circ} \mathrm{C}, 25^{\circ} \mathrm{C}$ and $37^{\circ} \mathrm{C}$, and PTT was determined for each sample at intervals of $1-12 \mathrm{~h}$ (Table 5). The PTT of the original plasma was $14.8 \mathrm{~s}$. Prolongations of PTT during $24 \mathrm{~h}$ incubation were $1.6 \mathrm{~s}$ at $4^{\circ} \mathrm{C}$ and $2.4 \mathrm{~s}$ at $25^{\circ} \mathrm{C}$. Under incubation at $37^{\circ} \mathrm{C}$, fibrin clot formation was incomplete after $6 \mathrm{~h}$ and no clot was formed after $12 \mathrm{~h}$.

\section{Activated Pariial Thromboplastin Time (APTT)}

As shown in Table 3, mean, standard deviation and range of APTT were $5.1 \mathrm{~s}, 0.7 \mathrm{~s}$, and 4.2-6.9 s, respectively. The correlation coefficient was 0.80 between PT and APTT, and was 0.81 between PTT and APTT. Since clot formation was very 
Table 5. Changes of PTT during incubations at $4^{\circ} \mathrm{C}$, $25^{\circ} \mathrm{C}$ and $37^{\circ} \mathrm{C}$

\begin{tabular}{cccc}
\hline $\begin{array}{c}\text { Incubation } \\
\text { time (h) }\end{array}$ & $37^{\circ} \mathrm{C}$ & $25^{\circ} \mathrm{C}$ & $4^{\circ} \mathrm{C}$ \\
\hline 0 & $14.8 \mathrm{~s}$ & 14.8 & 14.8 \\
1 & 17.1 & 14.8 & - \\
2 & 18.0 & 14.3 & - \\
3 & 19.5 & 14.4 & - \\
6 & 26.8 & 15.7 & - \\
12 & not clot & 16.0 & 14.8 \\
24 & & 17.2 & 16.4 \\
\hline
\end{tabular}

Table 6. Changes of APTT during incubations at $4^{\circ} \mathrm{C}, 25^{\circ} \mathrm{C}$ and $37^{\circ} \mathrm{C}$

\begin{tabular}{cccc}
\hline $\begin{array}{c}\text { Incubation } \\
\text { time (h) }\end{array}$ & $37^{\circ} \mathrm{C}$ & $25^{\circ} \mathrm{C}$ & $4^{\circ} \mathrm{C}$ \\
\hline 0 & $4.8 \mathrm{~s}$ & 4.8 & 4.8 \\
1 & 5.1 & 4.8 & - \\
2 & 5.4 & 5.2 & - \\
3 & 5.4 & 5.3 & - \\
6 & 5.8 & 5.2 & - \\
12 & not clot & 5.3 & 5.0 \\
24 & & 5.1 & 5.1 \\
\hline
\end{tabular}

fast, skill seems to have a large influence upon errors in APTT measurement.

Changes of APTT during Incubation at $4^{\circ} \mathrm{C}, 25^{\circ} \mathrm{C}$ and $37^{\circ} \mathrm{C}$

Pooled citrated plasma samples sub-divided into 3 tubes were incubated at $4^{\circ} \mathrm{C}, 25^{\circ} \mathrm{C}$ and $37^{\circ} \mathrm{C}$, and APTT was determined for each sample at intervals of $1-12 \mathrm{~h}$ (Table 6). The APTT of the original plasma was $4.8 \mathrm{~s}$. Prolongations of APTT during $24 \mathrm{~h}$ incubation were $0.4 \mathrm{~s}$ at both $4^{\circ} \mathrm{C}$ and $25^{\circ} \mathrm{C}$. Under incubation at $37^{\circ} \mathrm{C}$, fibrin clot formation was incomplete after $12 \mathrm{~h}$.

\section{Discussions}

The citrated plasma incubated at $37^{\circ} \mathrm{C}$ lost its clotting activity within $12 \mathrm{~h}$. On the other hand, plasma incubated at $4^{\circ} \mathrm{C}$ and $25^{\circ} \mathrm{C}$ maintained their clotting activity for more than $24 \mathrm{~h}$, and no remarkable differences were found between their clotting times. This indicates that the heat labile factors are quickly destroyed at $37^{\circ} \mathrm{C}$ while they can remain for many hours at $25^{\circ} \mathrm{C}$. In this study, $37^{\circ} \mathrm{C}$ was adopted as the test temperature, because it was necessary to use commercially available reagents prepared from rabbit brain in order to obtain reproducible results. Fujikata and Ikeda $^{18)}$ reported that the shortest clotting time was obtained at $34^{\circ} \mathrm{C}$.

It is noteworthy that APTT was very short compared with PTT. The reagent for APTT determination contains ellagic acid, which activates factor XII at a concentration of $10^{-8} \mathrm{M}$ in mammalian plasma. ${ }^{17)}$ The present result suggests that the XII-like factor exists and the intrinsic coagulation mechanism is highly developed in carp blood.

The deficient coagulation factors in adsorbed plasma with $\mathrm{BaSO}_{4}$ and stored serum completely supplemented each other by mixing. Although the properties and characteristics of the coagulant factors have not been fully investigated in fishes, coagulant factors in carp blood can be classified into two categories: the serum factors and the barium sulphate adsorbed factors.

This work was supported by Grant-in-Aid for Scientific Research (57560191) from the Ministry of Education.

\section{References}

1) R.F. Doolittle and D. M. Surgenor: Am. J. Physiol., 203, 964-970 (1962).

2) R.F. Doolittle: Brit. J. Haemat., 9, 464-470 (1963).

3) J. H. Lewis: Comp. Biochem. Physiol, A., 42, 233-240 (1972).

4) R. Holst: J. Physiol. (Lond.), 247, 32-33 (1975).

5) R. E. Feeney, J. Vandenheede, and D. T. Osuga: Naturwissensch., 59, 22-29 (1972).

6) C. Hougie: Adv. Exp. Med. Biol., 22, 89-102 (1971).

7) M. Katz and M. Southward: Copeia, 1950, 150 (1950).

8) A. K. Srivastava, S. J. Agrawal, and H.S. Chaudhry: Ecotoxicol. Environ. Safety, 3, 321324 (1979).

9) G. K. Iwama, G. K. Greer, and P. A. Larkin: J. Fish. Res. Bd. Canada, 33, 285-289 (1976).

10) T. Ochiai and S. Kubota: Bull. Fac. Fish. Mie Univ., 5, 129-153 (1978).

11) A. K. Srivastava and S. J. Agrawal: Acta Pharmacol. Toxicol. (Copenn.), 44, 197-199 (1979).

12) J. Mishra and A. K. Srivastava: Environ. Res., 30, 393-398 (1983).

13) S. Verma, S. Bansal, A. Gupta, and R. Dalela: Bull. Environ. Contam. Toxicol., 22, 467-474 (1979).

14) E. Casillas and L. S. Smith: J. Fish Biol., 10, 481-491 (1977).

15) A. Fujikata and Y. Ikeda: Bull. Japan. Soc. Sci. Fish., 51, 1093-1096 (1985).

16) A. Fujikata and Y. Ikeda: Bull. Japan. Soc. Sci. Fish., 51, 933-939 (1985).

17) O. D. Ratnoff: in "Progress in hematology" (ed. by C. V. Moore and E. Brown), Vol. 5, Grune \& Stratton, New York and London, 1966, pp. $204-244$. 